
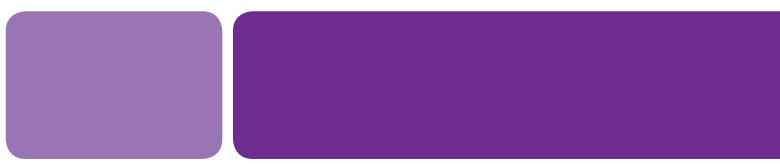

\title{
Financial aspects of community pharmacies in Slovakia (2009-2014) Finančné aspekty verejných lekární na Slovensku v rokoch 2009-2014
}

Abstract Community pharmacies play an important role in the process of ensuring public health. Pharmacists provide pharmaceutical care that includes acquiring, storing, preparing, reviewing and dispensing medicines, medical devices and dietary food to the inhabitants; providing them with information and advice; acquiring, storing and dispensing additional assortment; carrying out physical and biochemical testing for primary prevention and monitoring of drug efficacy and safety. At present, there are constant changes which have direct or potential and often negative impact on community pharmacies. For providing affordable and good quality pharmaceutical care, it is important to continuously monitor and analyse the developments in the financial data in community pharmacy business management. The data file from 2009-2014 on financial performance of selected community pharmacies were obtained from the Register of Financial Statements at Ministry of Finance Slovak Republic. A group of 194 community pharmacies were selected that represented more than 10 percent of all pharmacies. The selection criteria respected the territorial division of the Slovak Republic on districts, the size of municipalities (cities and villages) and location (at or near health centres, shopping centres, housing estates, etc.). The evaluation parameters were gross profit, net profit, revenue from sales of goods and services, operating expenses, total assets, inventory, short-term receivables, total receivables, financial assets, owner's equity, total liabilities, current liabilities and their characteristics $\left(25^{\text {th }}, 50^{\text {th }}, 75^{\text {th }}\right.$ percentile, minimum, maximum, mean). The financial parameters obtained and their characteristics presented the basic information on the management of community pharmacies. The data also provided information for further assessment on factors that might have an impact on their value and direction of evolution.

Slovak Verejné lekárne zohrávajú dôležitú úlohu v procese zabezpečenia verejného zdravia obyvatel’ov. Lekárnici zabezpečujú, abstract uchovávajú, pripravujú, kontrolujú a vydávajú lieky, zdravotnícke pomôcky, dietetické potraviny pre obyvatelov, poskytujú informácie a odborné rady, zabezpečujú, uchovávajú a vydávajú doplnkový sortiment, vykonávajú fyzikálne a biochemické vyšetrenia zamerané na primárnu prevenciu a sledujú účinnost' a bezpečnost' farmakoterapie. V súčasnej dobe dochádza k neustálym zmenám s priamym alebo potenciálnym vplyvom s často negatívnym dopadom na verejné lekárne. Na ich pochopenie a pozitívne využitie $v$ poskytovaní cenovo dostupnej a kvalitnej lekárenskej starostlivosti, je dôležité priebežne sledovat’ a analyzovat' vývoj finančných údajov manažmentu verejnej lekárne. Súbor údajov z obdobia 2009-2014 o finančnej výkonnosti vybraných verejných lekární bol získaný z Registra účtovných závierok Ministerstva financií Slovenskej republiky. Vzorku vybraných lekární tvorilo 194 verejných lekární, čo predstavovalo viac ako 10 percent všetkých lekární na Slovensku. Výberové kritériá zohladnili územné členenie Slovenskej republiky na okresy, vel'kost' obcí (mesto, dedina) a umiestnenie (zdravotné stredisko, nákupné centrum, sídlisko). Hodnotené boli parametre hrubý zisk, čistý zisk, tržby z predaja tovaru a služieb, prevádzkové náklady, celkové aktíva, zásoby, krátkodobé pohladávky, celkové pohladávky, finančné aktíva, vlastné imanie, celkové krátkodobé záväzky a ich deskriptíve charakteristiky (25., 50., 75. percentil, minimum, maximum, priemer). Získané finančné parametre a ich charakteristiky prezentujú základné informácie o obchodovaní verejných lekární a poskytujú informácie pre d’alšie hodnotenia faktorov, ktoré by mohli mat’ vplyv na ich hodnotu a smer vývoja.

Keywords community pharmacy-management-financial aspects

Klúčové verejná lekáreň - manažment - finančné aspekty

slová:

\section{INTRODUCTION}

Pharmaceutical care is one of the core areas of health care. Pharmaceutical care provides citizens with access to medicines, medical devices, dietetic food and supplementary products, usually within 24 hours, at least 5 days a week. Along with the aforementioned, it also provides expert advice on the correct use of medicines (Clifford et al., 2006, 
Blenkinsopp et al., 2000, Mináriková et al., 2015a), dietetic food, proper use of medical devices (Morrow et al., 1993, Malovecká et al., 2014, Malovecká et al., 2015a, Malovecká et al., 2015b) and expert advice in the field of prevention (Cain et al., 2001, O'loughlin et al., 1999), nutrition (Howard et al., 2001, Mináriková, 2015b), diet and a healthy lifestyle (Chewning and Schommer 1996, Kapoor, 2007). In recent years, community pharmacies have undergone a significant transformational change (Malovecká et al., 2015c). Prevailing among them are private properties and independent management of their business (Malovecká et al., 2015d). Provision of pharmaceutical care is solely the decision of the owner and that, like any business entity, is managed with the long-term sustainability of a community pharmacy (Malovecká et al., 2015e).

Pharmaceutical care in European countries is provided in a regulated or a deregulated system. The type of the regulation of pharmaceutical care has an impact on its availability, quality and economic stability of the community pharmacies. The introduction of deregulation in the establishment of community pharmacy was to ensure adequate availability of pharmaceutical care, evenly distributed between regions, especially between urban and rural areas (such as, England, Ireland, Netherlands, Norway and Sweden). In countries, such as Norway and Sweden, the introduction of deregulation has led to an increase in the number of community pharmacies, and in particular, to their uneven distribution within the country (more in cities, much less in the countryside) (Westerlud et al., 2006, Balgard, 20112, Todd et al., 2014, Wagner et al., 2009). In countries with deregulated pharmaceutical care, intervention in the ownership rules (concession or lack of ownership rules) has led to the establishment of a new structure that provides pharmaceutical care through a network of community pharmacies and vertical integrations with large international wholesale companies owning pharmacy chains that often control the market (seen mainly in Norway) (Vogler et al., 2012). This situation may affect the availability of medicines in pharmacies, as well as overall patient satisfaction with pharmaceutical care (Mináriková, 2015c, Mináriková et al., $2015 d)$. Therefore, the presence of measures relating to the availability of medicines in stock (FIP/WHO, 2012) and the time taken by the pharmacy to provide medications (present in some countries such as Austria, Denmark, Finland, Norway and Spain), could help to prevent a shortage of medicines and shorten the long waiting times for patients (Vogler et al., 2006). Equally important in this context is the electronic health system, which increases the overall level of pharmacy services and patient satisfaction with the help of electronic prescription service and provides other benefits as well (Minarikova and Panayiotis, 2015e).

In Slovakia, there are no demographic and geographic regulation criteria for the establishment of a community pharmacy, and therefore, Slovakia can be included among countries with deregulated pharmaceutical care (Ministry of Health Slovak Republic, 2011).
The presented article provides an assessment of the financial development in community pharmacies in deregulated pharmaceutical care in the horizon of six years (2009-2014), and its aim is to highlight the evolution of financial parameters which could be used in the description of community pharmacies' management.

\section{METHODS}

\section{Data source}

The data files from 2009-2014 on the financial performance of selected community pharmacies were from the Register of Financial Statements (profit and loss statement and balance sheet) at Ministry of Finance of the Slovak Republic (Ministry of Finance of the Slovak Republic, 2015). The financial statements for the time span 2009-2011 were in scanned form (typewriter or handwritten), and the financial statements for the time span 2012-2014 were in electronic spreadsheets. The financial data was available only for the community pharmacies that were running their business in a legal form as limited liability companies (Ltd.).

\section{Selection criteria}

A selected group of pharmacies consisted of 194 community pharmacies and represented more than 10 percent of all the pharmacies in Slovakia. The selection criteria respected the territorial division of the Slovak Republic. There are 79 districts in Slovakia. From each district, 2 community pharmacies were selected (hence, a total of 158 pharmacies) and subsequently, the group was supplemented by community pharmacies from districts with higher populations (36 pharmacies). The selection process took into account the size of municipalities (city or village) and location (at or near health centres, shopping centres and housing estate).

\section{Valuated parameters}

The data file on financial performance of selected community pharmacies was evaluated on gross profit, net profit, revenues from sales of goods and services, operating expenses, total assets, inventory, short-term receivables, total receivables, financial assets, owner's equity, total liabilities, and current liabilities. Microsoft Excel was used to process the data. The outcomes of the evaluation were organised and presented in tables.

\section{RESULTS AND DISCUSSION}

In the assessed period 2009-2014, the valuation revealed that $25 \%$ ( $25^{\text {th }}$ percentile) pharmacies reached gross profit from -2119 to 533 euro, next $50 \%$ ( $75^{\text {th }}$ percentile) pharmacies reached from 34016 to 45606 euro, and the last 25\% 
Table 1. The characteristics of community pharmacies by gross profit, net profit, revenues from sales of goods and services, and operating expenses in the years 2009-2014 (in euro)

\begin{tabular}{|c|c|c|c|c|c|c|}
\hline $\begin{array}{c}\text { Characteristics / } \\
\text { Years }\end{array}$ & 2009 & 2010 & 2011 & 2012 & 2013 & 2014 \\
\hline \multicolumn{7}{|c|}{ Gross profit } \\
\hline Mean & 31138 & 45229 & 24910 & 20393 & 23939 & 24473 \\
\hline Median & 6077 & 11383 & 11383 & 3332 & 13390 & 11047 \\
\hline Maximum & 1440286 & 1490174 & 1490174 & 1000168 & 337477 & 254877 \\
\hline Minimum & -248791 & -105815 & -105815 & -927603 & -159160 & -181426 \\
\hline 25th percentile & -349 & 533 & 533 & -2119 & -353 & -892 \\
\hline 75th percentile & 37405 & 45606 & 45606 & 34016 & 36912 & 35484 \\
\hline \multicolumn{7}{|c|}{ Net profit } \\
\hline Mean & 24236 & 32843 & 13204 & 15231 & 17370 & 19483 \\
\hline Median & 3687 & 9579 & 7877 & 2553 & 10033 & 8143 \\
\hline Maximum & 1137775 & 1088040 & 1235623 & 616017 & 258815 & 373673 \\
\hline Minimum & -249954 & -105815 & -3319209 & -327603 & -162447 & -173194 \\
\hline 25th percentile & -349 & 532 & 501 & -2119 & -828 & -2577 \\
\hline 75th percentile & 30733 & 41876 & 37895 & 25810 & 28365 & 27775 \\
\hline \multicolumn{7}{|c|}{ Revenues from sales of goods and services } \\
\hline Mean & 815225 & 914589 & 1031862 & 923748 & 1005378 & 1000871 \\
\hline Median & 693482 & 758778 & 807154 & 754987 & 762735 & 773027 \\
\hline Maximum & 6949428 & 4695606 & 14847567 & 6623654 & 7397353 & 6997364 \\
\hline Minimum & -4501 & -216 & -2619 & 2434 & 0 & 0 \\
\hline 25th percentile & 341738 & 380431 & 380499 & 404686 & 421549 & 402216 \\
\hline 75th percentile & 1111373 & 1201721 & 1285224 & 1240575 & 1294112 & 1232108 \\
\hline \multicolumn{7}{|c|}{ Operating expenses } \\
\hline Mean & 795808 & 822197 & 1018059 & 874036 & 994727 & 989613 \\
\hline Median & 634541 & 652969 & 745015 & 695439 & 754319 & 751378 \\
\hline Maximum & 7123156 & 4797196 & 18162063 & 6138078 & 7344317 & 6922814 \\
\hline Minimum & 0 & 0 & 0 & 9232 & 24 & 0 \\
\hline 25th percentile & 324406 & 331039 & 373119 & 355594 & 408809 & 404852 \\
\hline 75th percentile & 1111197 & 1105940 & 1263736 & 1179309 & 1255667 & 1216923 \\
\hline
\end{tabular}

(maximum) pharmacies reached from 254887 to 1490174 euro per year. Since 2011 , the maximum value of the gross profit was falling (from 1490174 euro in 2011 to 254877 euro in 2014). Mean gross profit (from 20393 to 45229 euro) was above the median (from 3332 to 13390 euro), and that showed that more pharmacies ran their businesses with lower gross profits.

From the group of community pharmacies, $25 \%\left(25^{\text {th }}\right.$ percentile) reached the net profit from - 2577 to 532 euro, next $50 \%$ ( $75^{\text {th }}$ percentile) pharmacies from 25810 to 41876 euro, and the last $25 \%$ (maximum) pharmacies up to 258 815 - 1235623 euro per year. Since 2011, the maximum net profit fell from 1235623 euro in 2011 to 373673 euro in 2014. Mean (from 13204 to 32843 euro) was again above the median (from 3687 to 10033 euro) and pointed out that more pharmacies run their business with lower net profit.

The assessment of revenues from sales of goods and services showed a big gap between $75^{\text {th }}$ percentile (from 1111373 to 1294112 euro) and maximum (from 4695 606 to 14847567 euro) per year. It means that only some pharmacies could generate high revenue from the sales of goods and services. Half of the pharmacies $\left(50^{\text {th }}\right.$ percentile/ median) generated revenue from sales of goods and services in the range of 693482 to 807154 euro per year.

Valuation of operating expenses reported on a big gap between $75^{\text {th }}$ percentile (from 1105940 to 1263736 euro) and maximum (from 4797196 to 18162063 euro) per year. It means that some pharmacies had very high operating costs. Other pharmacies kept their operating expenses lower (50 ${ }^{\text {th }}$ percentile, from 634541 to 754319 euro) and some pharmacies operated with much lower expenses $\left(25^{\text {th }}\right.$ percentile, from 324406 to 408809 euro) per year.

The evaluation of total assets revealed that maximum of the valuated characteristics had an increasing trend (from 1502264 euro in 2009 to 4307081 euro in 2014). Other valuated characteristics of parameter were almost stable $\left(25^{\text {th }}\right.$ percentile from 126656 to 139988 euro; $50^{\text {th }}$ percentile from 233256 to 262247 euro; $75^{\text {th }}$ percentile from 448778 to 482 807 euro).

The maximum of inventory fell slightly from 389781 in 2009 to 316476 euro, but in 2014, it increased up to 555353 euro. 
Table 2. The characteristics of community pharmacies by total assets, inventory, short-term receivables and total receivables in the years 2009-2014 (in euro)

\begin{tabular}{|c|c|c|c|c|c|c|}
\hline $\begin{array}{c}\text { Characteristics / } \\
\text { Years }\end{array}$ & 2009 & 2010 & 2011 & 2012 & 2013 & 2014 \\
\hline \multicolumn{7}{|c|}{ Total assets } \\
\hline Mean & 326886 & 376996 & 395603 & 378534 & 385069 & 380474 \\
\hline Median & 238662 & 252202 & 262347 & 233256 & 237126 & 240619 \\
\hline Maximum & 1502264 & 2711992 & 3420231 & 3310664 & 4158475 & 4307081 \\
\hline Minimum & 0 & 0 & 11099 & 15035 & 2898 & 0 \\
\hline 25th percentile & 130027 & 139988 & 138793 & 126656 & 134948 & 132086 \\
\hline 75th percentile & 448778 & 491027 & 503447 & 483495 & 482807 & 494298 \\
\hline \multicolumn{7}{|c|}{ Inventory } \\
\hline Mean & 60940 & 68614 & 72678 & 71437 & 70937 & 74471 \\
\hline Median & 53425 & 57848 & 56718 & 58471 & 60536 & 64447 \\
\hline Maximum & 389781 & 376661 & 390385 & 387752 & 316476 & 555353 \\
\hline Minimum & 0 & 0 & 0 & 0 & 0 & 0 \\
\hline 25th percentile & 28189 & 34887 & 36080 & 34323 & 36332 & 33440 \\
\hline 75th percentile & 78091 & 90177 & 91534 & 91748 & 87961 & 89445 \\
\hline \multicolumn{7}{|c|}{ Short-term receivables } \\
\hline Mean & 128737 & 151028 & 169739 & 147031 & 148060 & 142338 \\
\hline Median & 95771 & 97390 & 121156 & 95341 & 98005 & 90884 \\
\hline Maximum & 1074495 & 1951133 & 2362549 & 2251972 & 3083673 & 3315942 \\
\hline Minimum & 0 & -18884 & 0 & -11278 & -3622 & -8046 \\
\hline 25th percentile & 40625 & 42129 & 57972 & 42268 & 48762 & 42122 \\
\hline 75th percentile & 163672 & 183975 & 211236 & 172482 & 160848 & 161176 \\
\hline \multicolumn{7}{|c|}{ Total receivables } \\
\hline Mean & 134056 & 157830 & 176382 & 151293 & 152933 & 146966 \\
\hline Median & 103177 & 102626 & 125517 & 98292 & 98074 & 96080 \\
\hline Maximum & 1076654 & 1951133 & 2362549 & 2251972 & 3083673 & 3315942 \\
\hline Minimum & -173 & -18884 & 1148 & -11278 & -3622 & -8046 \\
\hline 25th percentile & 50203 & 51081 & 60032 & 48610 & 49778 & 43683 \\
\hline 75th percentile & 166394 & 202709 & 217327 & 190851 & 163150 & 163842 \\
\hline
\end{tabular}

Up to $75 \%$ ( $75^{\text {th }}$ percentile) pharmacies kept inventory from 78901 euro to 91748 euro; $50 \%$ ( $50^{\text {th }}$ percentile) from 53425 to 64447 euro and $25 \%$ ( $25^{\text {th }}$ percentile) from 28189 to 36 332 euro.

The maximum of short-term receivables increased considerably from 1074495 euro in 2009 to 3315942 euro in 2014. In contrast, since 2011, all the remaining valuated characteristics were falling ( $75^{\text {th }}$ percentile from 211236 to 161176 euro, $50^{\text {th }}$ percentile from 121156 euro to 90884 euro, $25^{\text {th }}$ percentile from 57972 euro to 42122 euro).

The total receivables followed the same pattern as the shortterm receivables. This was due to the fact that total receivables were predominantly made up of short-term receivables. The maximum of total receivables rose from 1076654 euro in 2009 up to 3315942 euro in 2014, but the rest of the valuated characteristics since 2011 fell $\left(75^{\text {th }}\right.$ percentile from 217327 to 163842 euro, $50^{\text {th }}$ percentile from 125517 to 96080 euro, $25^{\text {th }}$ percentile from 60032 to 43683 euro).

The assessment of financial assets exposed that maximum of the valuated parameters had an increasing trend (from 446
232 euro in 2009 to 834320 euro in 2014). The $25^{\text {th }}$ percentile was nearly stable (from 6863 to 9414 euro). Higher oscillation expressed $50^{\text {th }}$ percentile (from 21387 to 30448 euro) and the highest oscillation had $75^{\text {th }}$ percentile (from 45257 to 73 310 euro).

The owners' equity expressed a remarkable evolution. The slight changes in $25^{\text {th }}$ percentile that reached values from 6 031 to 8951 euro and $50^{\text {th }}$ percentile that reached values from 26699 to 47125 euro were in contrast with the mean (69 224 to 136332 euro) and $75^{\text {th }}$ percentile (79 299 to 172704 euro), where we recorded a significant increase. That points to the fact that owners were showing lower interest in loans and were increasingly financing their businesses from their own resources.

In the assessed period, the total liabilities showed a decreasing trend in almost all valuated characteristics (25 $5^{\text {th }}$ percentile from 90601 in 2009 to 79525 in 2014, 50 $0^{\text {th }}$ percentile from 174944 euro in 2009 to 162175 euro in 2014, $75^{\text {th }}$ percentile 364313 in 2009 to 342953 euro in 2014). Contrary to the presented characteristics of parameter is 
Table 3. The characteristics of community pharmacies by financial assets, owner's equity, total liabilities and current liabilities in the years 2009-2014 (in euro)

\begin{tabular}{|c|c|c|c|c|c|c|}
\hline $\begin{array}{c}\text { Characteristics / } \\
\text { Years }\end{array}$ & 2009 & 2010 & 2011 & 2012 & 2013 & 2014 \\
\hline \multicolumn{7}{|c|}{ Financial assets } \\
\hline Mean & 54430 & 57488 & 48924 & 51846 & 56373 & 61771 \\
\hline Median & 28601 & 30448 & 21387 & 21755 & 26974 & 24409 \\
\hline Maximum & 446232 & 530620 & 653468 & 694315 & 820912 & 834320 \\
\hline Minimum & -48315 & -76788 & -49792 & -43962 & -32318 & -14074 \\
\hline 25th percentile & 7903 & 9414 & 7525 & 6871 & 6863 & 6905 \\
\hline 75th percentile & 68246 & 69279 & 45257 & 58461 & 66153 & 73310 \\
\hline \multicolumn{7}{|c|}{ Owner's equity } \\
\hline Mean & 69224 & 91840 & 85148 & 77824 & 118451 & 136332 \\
\hline Median & 26699 & 38398 & 47125 & 39163 & 42152 & 42717 \\
\hline Maximum & 1166573 & 2132270 & 2142819 & 2117949 & 2094620 & 2595958 \\
\hline Minimum & -320689 & -248302 & -3557662 & -4485266 & -194999 & -146592 \\
\hline 25th percentile & 6230 & 7852 & 8951 & 6362 & 8198 & 6031 \\
\hline 75th percentile & 79299 & 99957 & 128330 & 128558 & 159396 & 172704 \\
\hline \multicolumn{7}{|c|}{ Total liabilities } \\
\hline Mean & 259734 & 282672 & 313351 & 303687 & 301591 & 285896 \\
\hline Median & 174944 & 188606 & 198104 & 169578 & 174580 & 162175 \\
\hline Maximum & 1822953 & 2614204 & 5176998 & 4518491 & 4518547 & 4335779 \\
\hline Minimum & -1672 & -3521 & 2337 & 1734 & 148 & -790 \\
\hline 25th percentile & 90601 & 104948 & 103856 & 88359 & 86512 & 79525 \\
\hline 75th percentile & 364313 & 363292 & 379350 & 364253 & 335733 & 342953 \\
\hline \multicolumn{7}{|c|}{ Current liabilities } \\
\hline Mean & 221669 & 239853 & 264364 & 292335 & 253190 & 236793 \\
\hline Median & 146835 & 165962 & 163917 & 138132 & 148804 & 128875 \\
\hline Maximum & 1815381 & 2368508 & 5156333 & 9114421 & 4497815 & 4315030 \\
\hline Minimum & -2713 & -4574 & 0 & 286 & 0 & 0 \\
\hline 25th percentile & 78205 & 92572 & 84157 & 70021 & 63497 & 67863 \\
\hline 75th percentile & 300807 & 310298 & 300198 & 290270 & 275311 & 269946 \\
\hline
\end{tabular}

maximum, that rose in 2009-2011 from 1822953 to 5176998 euro and then slightly dropped to 4335779 euro.

The current receivables expressed nearly the same proceedings as the total liabilities in case of $25^{\text {th }}, 50^{\text {th }}$ and $75^{\text {th }}$ percentiles. These characteristics showed a decreasing trend ( $25^{\text {th }}$ percentile from 78205 to 67863 euro, $50^{\text {th }}$ percentile from 146835 to 128875 euro, $75^{\text {th }}$ percentile from 300807 to 269946 euro). Only the maximum of current liabilities expressed an inclining trend in 2009-2012 from 1815381 to 9 114421 euro. In the following period 2013-2014, a declining trend was recorded to 4315030 euro.

The evaluation of financial parameters and their characteristics presents the basic information on the financial development, performance and management of selected community pharmacies in the period 2009-2014. They provide us with unique information that has never been the subject of investigation and publication of any national, private or professional association on such a large sample of community pharmacies, neither in the Slovak Republic nor in Europe. The presented data can be used for further assessment of factors (such as legislation, demographic development, health needs of population, etc.) that might have an impact on their value and direction of evolution. Unrepresentative sample of observed pharmacies could cause huge differences between pharmacies in all financial parameters. Practical findings will be required for further analysis in this field.

The work assesses the areas that should be the subject of follow-up and in-depth evaluation, or that can be the basis for the proposal of additional research. The evaluation of community pharmacy operations and overall performance is nowadays very crucial as the European Union countries are more or less facing the consequences of the financial crisis, recession and serious socioeconomic and political changes.

\section{CONCLUSIONS}

The European community pharmacy sector is a highly regulated area with various degrees of liberalization in individual countries. Liberalization in community pharmacy usually comprises of liberalization of the establishment 
rules for new pharmacies, ownership and OTC medicines' sale outside the pharmacies. Liberalization in community pharmacy in Slovakia, according to the legislative changes valid from the year 2004, brought new conditions of establishment of new pharmacies without any demographic and geographic criteria. The impact of this liberalization on medicine prices or on availability of medicines is expected, but the evidence about this impact on the pharmacies market is still absent. Independently, from the extent of regulation in community pharmacy, the policy-makers are recommended to monitor and evaluate the impact of the policy measures, and wherever required, to take an action in order to ensure equitable accessibility of medicines, enhance sustainable competition and avoid negative implications to the detriment of patients and community pharmacies as profitable entities.

\section{References}

[1] Balgard M. The new pharmacy market in Sweden.Eur J Hosp Pharm. (2012) 19 (1): 23-25.

[2] Blenkinsopp A, Phelan M, Bourne J, Dakhil N. Extended adherence support by community pharmacists for patients with hypertension: a randomised controlled trial. International Journal of Pharmacy Practice. (2000) 8(3): 165-175.

[3] Cain WT, Cable G, Oppenheimer JJ. The ability of the community pharmacist to learn the proper actuation techniques of inhaler devices. J Allergy Clin/mmunol. (2001) 108(6): 918-920.

[4] Chewning B, Schommer JC. Increasing clients' knowledge of community pharmacists' roles. Pharmaceut Res. (1996) 13(1): 1299-1304.

[5] Clifford S, Barber N, Elliott R, Hartley E, Horne R. Patient-centred advice is effective in improving adherence to medicines. Pharm World Sci. (2006) 28(1): 165-170.

[6] FIP/WHO. Good Pharmacy Practice. Guidelines on GPP: Standards for quality of pharmacy services. Hague: FIP (2012) 20.

[7] Howard N, Tsourounis C, Kapusnik-Uner J. Dietary supplement survey of pharmacists: personal and professional practices. $J$ Altern Complement Med. (2001) 7(6): 667-680.

[8] Kapoor S. Effectiveness of visits from community pharmacists for patients with heart failure: HeartMed randomised controlled trial. BMJ. (2007) 334(7603): 1098.

[9] Malovecká I, Vidrová J, Mináriková D, Foltán V. Spending of medical devices in Slovakia. Acta Fac Pharm UnivComen. (2014) 61(2): 35-41.

[10] Malovecká I, Mináriková D, Foltán V. Zdravotnícke pomôcky a ich utilizácia. Farmakoekonomika a liekovápolitika. (2015a) 11(1-2): 9-15.

[11] Malovecká I, Mináriková D, Foltán V. Zdravotnícke pomôcky vybrané úlohy Výdaj zdravotníckych pomôcok na lekársky poukaz. Bratislava: Farmaceutickáfakulta UK (2015b) 230.

[12] Malovecká I, Mináriková D, Foltán V. The change of demographic indicators, the legal form of the ownership, the owner share of a pharmacist in the capital and economic situation in the community pharmacies resulting from globalization. Social pharmacy in health care.(2015c) 1(1): 32-37.

[13] Malovecká I, Mináriková D, Foltán V. Impact of new healthcare legislation and price policy on healthcare services provider at the time of financial crisis. A 10 years study. Farmaconomia. Health economics and therapeutic pathways.(2015d) 16(1): 15-24.

[14] Malovecká I, Mináriková D, Foltán V. Prosperity of community pharmacy evaluated by gross and net profit and suggested corrective measures. 10 years study. ActaFac Pharm UnivComen. (2015e) 62(1): 20-24.

[15] Mináriková D, Foltán V, Malovecká I. Zdravotnícke pomôcky. Legislatíva a regulácia. Martin: Osveta (2015a) 222.

[16] Mináriková D, Minárik P, Foltán V. Zinok a prechladnutie hodnotenie poradenstva metódou "mystery customer". Súč Klin Prax. (2015b) 2(1): 26-31.

[17] Mináriková D. Úroveň a faktory ovplyvňujúce pacientsku spokojnost's lekárenskou starostlivostou na Slovensku. Čes Slov Farm. (2015c) 64(5): 178-183.

[18] Mináriková D, Malovecká I, Foltán V. Consumer satisfaction with pharmaceutical care in Slovak community pharmacies. Acta Fac Pharm Univ Comen. (2015d) 62(1): 25-30.

[19] Minarikova D, Panayiotis A. Electronic prescription services system in Greece - pilot study. Acta Pol Pharm. (2015e) 72 (6): 1295-1302.

[20] Ministry of Finance. Register of financial statements. http://www. registeruz.sk/cruz-public/home/

[21] Ministry of Health. Law on pharmacy. Official Journal of Ministry of Health Slovak republic No. 362/2011 Coll. Act (in Slovak language).

[22] Morrow N, Hargie O, Woodman C. Consumer perceptions of and attitudes to the advice-giving role of community pharmacists. Pharm J. (1993) 251(1): 25-27.

[23] O'loughlin J, Masson P, Déry V, Fagnan D. The role of community pharmacists in health education and disease prevention: a survey of their interests and needs in relation to cardiovascular disease. Prev Med. (1999) 28(3): 324-331.

[24] Todd A, Copeland A, Husband A, Kasim A, Bambra C. The positive pharmacy care law: an area-level analysis of the relationship between community pharmacy distribution, urbanity and social deprivation in England. BMJ Open. (2014) 4:e005764.

[25] Vogler S, Arts D, Sandberger K. Impact of pharmacy deregulation and regulation in European countries: Summary Report. Vienna: Austrian Health Institute (2012) 36.

[26] Vogler S, Habl C, Leopold C. Community pharmacy in Europe. Lessons from deregulation - case studies. Vienna: Austrian Health Institute (2006) 182.

[27] Wagner A, Hann M, Noyce P, Ashcroft D. Equity in the distribution of community pharmacies in England: impact of regulatory reform. J Health Serv Res Policy.(2009)14(4): 243-248.

[28] Westerlud T, Bjork TH. Pharmaceutical Care in Community Pharmacies: Practice and Research in Sweden. Ann Pharmacother. (2006) 40(6): 1162-1169. 